\title{
Tax Avoidance Level: Executive Characteristic, Independent Commissioner and Profitability in Indonesia Manufacture Company
}

\author{
$1^{\text {st }}$ Giawan Nur Fitria ${ }^{1}, 2^{\text {nd }}$ Ariza Roni Taufik ${ }^{2}$ \\ \{giawan.nur@mercubuana.ac.id ${ }^{1}$,dosen01128@unpam.ac.id² \\ Universitas Mercu Buana, Indonesia ${ }^{1}$, Universitas Pamulang, Indonesia ${ }^{2}$
}

\begin{abstract}
This research investigates the relationship between tax avoidance with executive characteristics, independent commissioner and profitability at manufacture firm in Indonesia. Tax avoidance was difference measure by using corporate tax to return ratio (CTTOR). This ratio present for tax avoidance level, in which higher CTTOR means the lower tax avoidance level. This study was using 20 manufacture firms in Indonesia. There were 80 annual reports data. This research used multiple regressions linear with SPSS 23 for tool analysis. The result shows the executive characteristics has negative impact but not significant to tax avoidance. Independence commissioner and profitability have positive significant effect to tax avoidance. Besides, size and total asset turn over and leverage has relationship with tax avoidance.
\end{abstract}

Keywords: Executive characteristics, Independent commissioner, Profitability, CITOR.

\section{Introduction}

The Panama Papers case was discussed in the spotlight of the Indonesian government, the Panama Papers became the biggest tax avoidance scandal that could even be classified as a practice of tax crime (1). Many businessmen from well-known companies in Indonesia were involved in the Panama Papers, entrepreneurs transferred their money to Panama to avoid taxation in Indonesia. This has become a serious problem for the Indonesian government, especially the Directorate General of Taxes, to improve the governance of the taxation system in Indonesia. Not only stop there, many cases of tax evasion by national and multinational companies include the case of the internet giant from the United States, Google which was busy discussed in 2016 by utilizing the status of its legal entity that claims that it is not a BUT (Permanent Establishment) and instead of claiming PMA (Foreign Investment) while in Indonesia PMA itself is not taxed and Google is always evasive when it wants to do an examination of the status of Google's legal entity.

Tax avoidance is part of the company's strategy related to the structure of transactions by tax law and legal provisions to reduce the level of tax payable. This reduction in legal tax debt can be a matter that is for the company (2). In this study tax avoidance uses indicators that have never been used before in accordance with the conditions of taxation in Indonesia, namely referring to SE-96 / PJ / 2009 regarding benchmarking ratios using several indicators to measure tax avoidance (3). The indicator used in this study is the Corporate Tax to turn Over Ratio (CTTOR). 
Top management as the highest of the company has a very important role as decision makers including tax saving decisions according to taxation theory (4). Tax avoidance by the company is of course through the policies taken by top management itself. Top management as decision makers and policies in the company certainly has different characters. A leader can have a risk taker character or risk avers which is reflected in the size or risk of the company (5). The higher the risk of a company, the executive tends to be a risk taker. Conversely, the lower the risk of a company, the executive will be risk averse. This study wanted to find out the role of top management in tax avoidance. The role of top management is seen in the form of risk in this study. Examined the effect of executive characteristics on tax avoidance (6). The results of this study are corporate risk has a positive effect on tax avoidance. this research has same result (7),(8). But different result with that character excecutive has no effect to tax avoidance (9).

Tax avoidance carried out by companies is of course influenced by the leaders of the company who are very instrumental in decision making, the Chief Executive Officer (CEO) can influence tax avoidance decisions by regulating the "tone at the top" related to corporate tax activities (10). An independent commissioner is has positive effect to tax avoidance (11). This result (12),(7). While, different result showed that independent commissioner has no effect to tax avoidance.

The profitability of a company reflects the company's financial performance. This ratio was chosen in this study because this ratio can measure how much the company's ability to generate net income from net sales (Kasmir, 2017). This ratio is considered important because net profit margins can indicate the survival of a company depends on the net sales it gets in a period. Prior research using return on asset as measurement of profitabilities (2),(13),(6). In this research will try to find the difference result if using different measurement of profitability and its effect to tax avoidance.

For developing countries such as Indonesia, they desperately need taxes as funds for state funding. Therefore, tax avoidance carried out by companies is a matter that is very detrimental to the state. For that reason, this research is very important to know what factors influence the company to do tax avoidance. Another reason is there was still different result from prior research.

Contributions from this study can provide a literature review of the characteristics of executives, independent commissioners, profitabilities for tax avoidance. Tax avoidance here is difference measured by detecting the possibility of tax avoidance by benchmarking (BM). In addition, the results of this study can provide input to the company management in making tax savings so that companies are more careful in taking tax avoidance actions, companies are expected to be able to avoid the risks that might occur due to inspection by the tax authority. Besides, the results of this study also provide input to investors to be careful in buying company shares. They required assessment of compliance from the company in carrying out its tax obligations so that can determine the stability of the company is running well.

\section{Literatur Reviews}

\subsection{Agency Theory}

Agency theory as a relationship between an agent (management) and a Principal (company owner) who are bound in a contractual manner (14). The Principal assigns tasks to 
agents to provide services for the benefit of the principal. In agency theory, it is known that there are work contracts that regulate the proportion of utility of each party while still taking into account the benefits as a whole.

\subsection{Tax Avoidance}

Tax avoidance is a transaction scheme to reduce the tax amount by making use of the loophole of tax regulation in a country. Tax avoidance can be conducted by (1) substantive tax planning which is transferring tax subject and tax object to tax haven or the government has given a special tax treatment; (2) Formal tax planning which is defending the economics substance from any transaction by choosing a formal transaction that can provide a lower tax requirement; (3) Anti tax avoidance regulation against the transfer pricing transaction, thin capitalization, treaty shopping and controlled foreign corporation (15). Tax avoidance is an effort to reduce or save taxes as long as this is made possible by existing regulations. An example of tax avoidance is directing transactions on transactions that are not tax objects (5).

\subsection{Characteristics Executive}

Everyone has different characteristics. Each individual has one of two characteristics, namely risk takers or risk avers (5). Executives who have the characteristics of a risk taker will be more willing to take risks in decision making. Conversely, risk avers is a characteristic of executives who do not like risk, so that in making business decisions, these executives will prefer to take smaller risk decisions.

\subsection{Independent Commissioner}

The Independent Commissioners is a corporate organ that has the task of supervising in general and / or specifically in accordance with the articles of association and divising the directors (UU NO. 40, 2007). An independent commissioner is defined as an unaffiliated person in all matters with a controlling shareholder, not serving as a director of a company related to the owner's company. The existence of independent commissioners based on the Indonesia Stock Exchange (BEI) regulation Number Kep-305 / BEJ / 07-2004 requires companies whose shares are listed on the Indonesia Stock Exchange (BEI) to have at least $30 \%$ independent commissioners from all members of the board of commissioners.

\subsection{Profitability}

Net Profit Margin is the profitability ratio used to measure the percentage of net profit in a company against its net sales. This Net Profit Margin shows the proportion of sales remaining after deducting all related costs. Net Profit Margin is often referred for investor. Net Profit Margin is the profitability ratio used to measure the percentage of net profit in a company against its net sales. By comparing net income with total sales, investors can see 
what percentage of income is used to pay for operational costs and non-operating costs and what percentage is left over which can pay dividends to shareholders or invest back into the company.

\section{Research Model, Hipotheses and Methodology}

\subsection{Research Model and Hypotheses}

Every manager has different characteristics. Stated that each individual has one of two characteristics, namely risk takers or risk avers (5). Executives who have the characteristics of a risk taker will be more willing to take risks in decision making. Conversely, risk avers is a characteristic of executives who do not like risk, so that in making business decisions, these executives will prefer to take smaller risk decisions. Examined the effect of executive characteristics on tax avoidance (5). The results of this study are corporate risk has a negative effect on tax avoidance. Examined the effect of executive characteristics on tax avoidance (6). The results of this study are corporate risk has a positive effect on tax avoidance. this research has same result (7)(8). But different result that character excecutive has no effect to tax avoidance (9). Then the hypothesis proposed is:

H1: Executive characteristics has negative effect to tax avoidance

Independent Commissioners are members of the Board of Commissioners who are from outside the company, the position of the board of commissioners is independent, basically the same as the other members of the board of commissioners, namely as a supervisory body and advisor to the directors (11). With the existence of strict controls carried out by independent commissioners, it is predicted that the aggressiveness of corporate taxes carried out by agents will be even less. An independent commissioner is has positive effect to tax avoidance (11). This result (12)(7). While, different result showed that independent commissioner has no effect to tax avoidance (Afni \& Hermawan, 2016)(18). Then the hypothesis proposed is:

$\mathrm{H} 2$ : Independence commissioner has positive effect to tax avoidance.

Net Profit Margin is the profitability ratio used to measure the percentage of net profit in a company against its net sales. This Net Profit Margin shows the proportion of sales remaining after deducting all related costs. Net Profit Margin is often referred to as the Profit Margin Ratio (Kasmir, 2017). Net Profit Margin is the profitability ratio used to measure the percentage of net profit in a company against its net sales. This Net Profit Margin shows the proportion of sales remaining after deducting all related costs. The more profit generated, the greater the tax that must be paid. Profitabilities has effect to tax avoidance (2)(13)(6). In this research will try to find the difference result if using different measurement of profitability and its effect to tax avoidance. Then the hypothesis proposed is:

H3: Profitability has positive effect to tax avoidance 
The research model in this study is as follow:

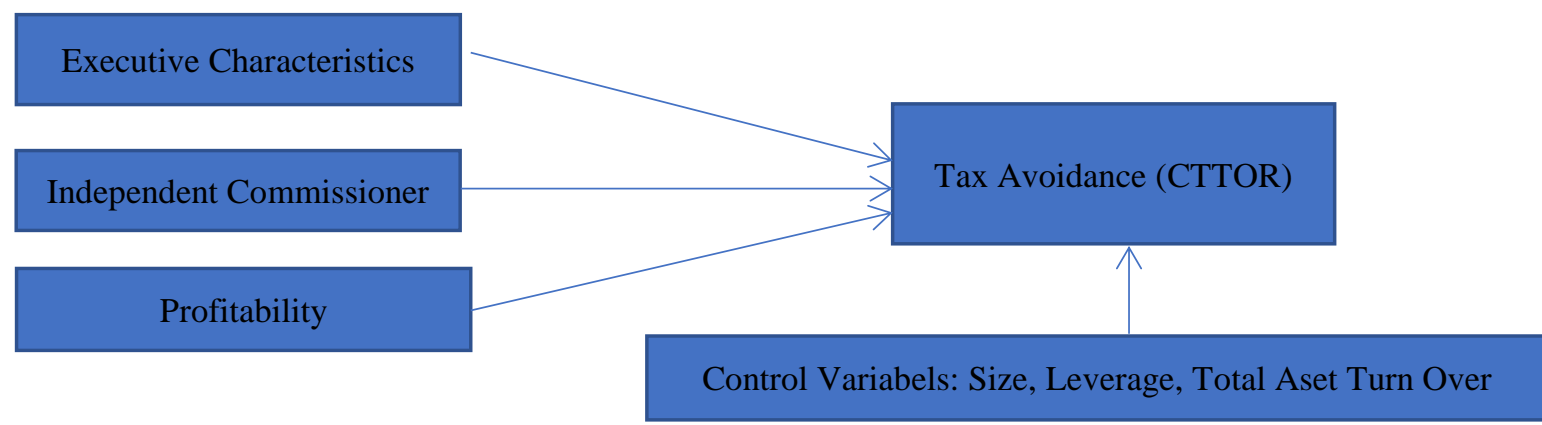

Fig. 1. Research Model

\subsection{Methodology Research Design}

The research design is causal research which aims to test hypotheses about the effect of independent variables on the dependent variable. This study was designed to find out and describe how the influence of executive characteristics, independent commissioners, profitability on tax avoidance.

The regression linear model is :

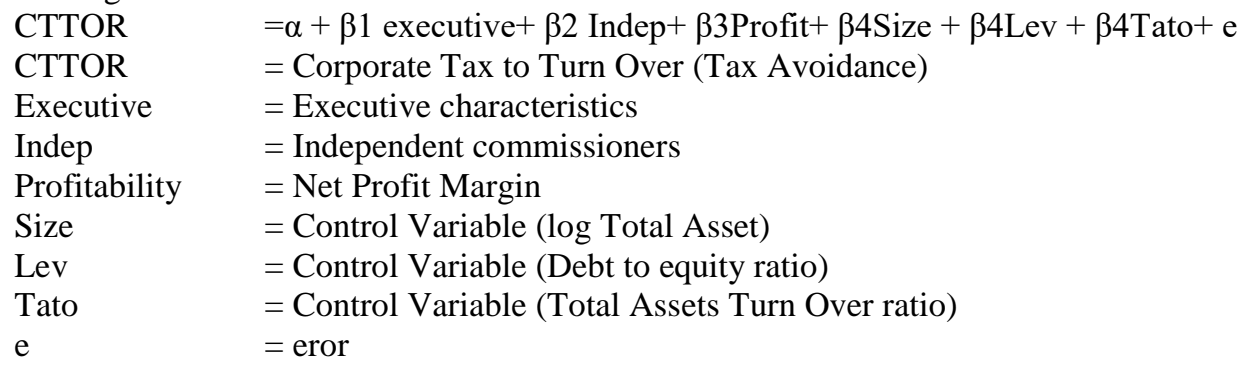

\subsection{Population and Sample}

The population in this research is the manufacture firm in chemical sector listed in Indonesia Stock Exchange. The sampling method used was a purposive sampling. The table below is the sample criteria.

Table 1. Population and Sample

\begin{tabular}{|c|c|c|}
\hline No. & Criteria & Amount \\
\hline 1 & Manufacture firm of chemical sector listing in Indonesia Stock & 48 \\
\hline
\end{tabular}




\begin{tabular}{|c|l|c|} 
& Exchange (population) & \\
\hline 2 & $\begin{array}{l}\text { Companies that do not report financial reports and annual reports } \\
\text { consistently from 2014-2017 }\end{array}$ & 6 \\
\hline 3 & $\begin{array}{c}\text { Companies that suffered losses in 2014-2017 } \\
\text { Total Sample (20 manufacture firms) }\end{array}$ & 22 \\
\hline \multicolumn{2}{|c|}{}
\end{tabular}

\section{Results and Discussion}

\subsection{Descriptive Statics}

Table 2. Descriptive Statistics

\begin{tabular}{|l|r|r|r|r|r|}
\hline & \multicolumn{1}{|c|}{$\mathrm{N}$} & Minimum & Maximum & \multicolumn{1}{c|}{ Mean } & Std. Deviation \\
\hline Excecutive & 80 & 3.00 & 38.00 & 11.6000 & 7.23144 \\
Indep & 80 & 29.00 & 60.00 & 39.8875 & 8.67558 \\
Profit & 80 & 1.00 & 23.00 & 8.0750 & 4.95237 \\
Size & 80 & 2562.00 & 3104.00 & 2814.6875 & 147.13867 \\
Lev & 80 & 8.00 & 181.00 & 66.6375 & 47.05377 \\
Tato & 80 & 31.00 & 163.00 & 94.3375 & 33.39520 \\
CTTOR & 80 & .00 & 5.00 & 2.1125 & 1.27283 \\
Valid N (listwise) & 80 & & & & \\
\hline
\end{tabular}

Descriptive statistics show that executive characteristics variables have an average of $11.6 \%$, which means to generate profits the top managers decide to use company assets on average by $11.6 \%$. The proportion of independent commissioners has an average value of $39.88 \%$. This shows that the sample companies have as many as 3 independent commissioners. Company profitability calculated by net profit margin has an average of $8.07 \%$, which means that the average company earns profit of $8.07 \%$ of total sales. Variable tax avoidance calculated by CTTOR shows an average number of $2.11 \%$, that the company pays an average tax of $2.11 \%$ of total net sales.

\subsection{Classic Assumption Tes and Goodness of Fit Model}

The data was normal and passed from classic assumption test like heterorcedaticity, multicolinearity, autocolleniarity.

Table 3. ANOVE 
ANOVA $^{a}$

\begin{tabular}{|rl|r|r|r|r|r|}
\hline \multicolumn{1}{|l|}{} & \multicolumn{1}{|c|}{$\begin{array}{c}\text { Sum of } \\
\text { Sodel }\end{array}$} & \multicolumn{1}{c|}{ Squares } & df & Mean Square & F & Sig. \\
\hline 1 & Regression & 64.264 & 6 & 10.711 & 12.270 & $.000^{\mathrm{b}}$ \\
& Residual & 63.724 & 73 & .873 & & \\
& Total & 127.988 & 79 & & & \\
\hline
\end{tabular}

a. Dependent Variable: CTTOR

b. Predictors: (Constant), Tato, Excecutive, Indep, Size, Lev, Profit

Based on the F-test on table 2 above, the significance is $0,000<0,05$. This shows that the model proposed in this study is quite good.

Table 4. Model Summary ${ }^{\mathrm{b}}$

Model Summary

\begin{tabular}{|l|c|r|r|r|r|}
\hline Model & $\mathrm{R}$ & R Square & $\begin{array}{c}\text { Adjusted R } \\
\text { Square }\end{array}$ & $\begin{array}{c}\text { Std. Error of } \\
\text { the Estimate }\end{array}$ & $\begin{array}{c}\text { Durbin- } \\
\text { Watson }\end{array}$ \\
\hline 1 & $.709^{\mathrm{a}}$ & .502 & .461 & .93431 & 2.105 \\
\hline
\end{tabular}

a. Predictors: (Constant), Tato, Excecutive, Indep, Size, Lev, Profit

b. Dependent Variable: CTTOR

\subsection{Hypotheses Result}

Table 5. Coefficients ${ }^{\mathrm{a}}$

Coefficients $^{a}$

\begin{tabular}{|c|c|c|c|c|c|c|c|c|}
\hline \multirow[b]{2}{*}{ Mod } & & \multicolumn{2}{|c|}{ Unstandardized Coefficients } & \multirow{2}{*}{$\begin{array}{c}\text { Standardized } \\
\text { Coefficients } \\
\text { Beta }\end{array}$} & \multirow[b]{2}{*}{$t$} & \multirow[b]{2}{*}{ Sig. } & \multicolumn{2}{|c|}{ Collinearity Statistics } \\
\hline & & $\mathrm{B}$ & Std. Error & & & & Tolerance & VIF \\
\hline \multirow[t]{7}{*}{1} & (Constant) & -1.576 & 2.229 & & -.707 & .482 & & \\
\hline & Excecutive & -.005 & .020 & -.028 & -.250 & .803 & .545 & 1.836 \\
\hline & Indep & -.020 & .012 & .137 & 1.638 & .011 & .978 & 1.023 \\
\hline & Profit & .152 & .030 & .592 & 5.113 & .000 & .509 & 1.965 \\
\hline & Size & .001 & .001 & .061 & .708 & .481 & .907 & 1.102 \\
\hline & Lev & -.006 & .003 & -.209 & -1.985 & .051 & .616 & 1.624 \\
\hline & Tato & .006 & .003 & .167 & 1.850 & .068 & .840 & 1.191 \\
\hline
\end{tabular}

a. Dependent Variable: CTTOR

According to t-test result in table 4.6, we found that: 
a. Executive characteristic has negative coefficient with significant level in 0,803 . It is mean that executive characteristic has negative effect and not significant to tax avoidance.

b. Independent commissioner has negative effect and significant in 0,011 to tax avoidance.

c. Profitability has positive effect and significant in 0,000 to tax avoidance.

d. Size has positive effect but not significant in 0,481 to tax avoidance.

e. Leverage has negative effect and significant in 0,051 to tax avoidance.

f. Total Assets turn overs has positive effect but not significant in 0,68 to tax avoidance. The regression linear are:

g. $\quad$ CTTOR $=-1,576-0,05$ executive $-0,20$ indep $+0,152$ profit $+0,01$ size $-0,06$ lev + 0,06 tato+e

\subsection{Relationship between executive characteristics with tax avoidance}

Every manager has different characteristics. Stated that each individual has one of two characteristics, namely risk takers or risk avers. Executives who have the characteristics of a risk taker will be more willing to take risks in decision making (5). Conversely, risk avers is a characteristic of executives who do not like risk, so that in making business decisions, these executives will prefer to take decisions with a smaller risk

Hypothesis 1, executive characteristics has positive effects to tax avoidance. If the manager is risk takers, they will do more the tax avoidance in order to minimize the tax debt.

As per hypotheses T-test result that hypothesis 1 was rejected. In this result, executive characteristics has negative effect but not significant. It is means that executive characteristic has a little effect to tax avoidance. Although the manager was risk taker, it does not mean they will do more tax avoidance. As per result, the executive characteristics do not have more effect to tax avoidance. This result was in line that executive characteristic has negative effect to tax avoidance(5)(7). But this result different with (6)

\subsection{Relationship between independent commissioners with tax avoidance}

The proportion of independent commissioners in the sample companies has an average of $39.88 \%$ with 3 to 4 person of independent commissioners in the sample companies. The existence of an independent commissioner at the company has shown the existence of supervision of management operations and decisions taken by management. Hypothesis 2, independent commissioner has negative effect to tax avoidance. It was means that more independent commissioner in the company, they can reduce tax avoidance. Independent commissioner act overseeing management decisions. The composition of the number of board of commissioners in companies can negative effect tax avoidance. Top management supervised by independent commissioners will work more carefully in making decisions to take steps to use the grey area taxation. Because if using grey area in taxation, that can lead company to an inspection from the tax authority. This result was in line with previous research (7)(15). 


\subsection{Relationship between profitability with tax avoidance}

In this research, profitability measures by net profit margin. For Investors, this Net Profit Margin is usually used to measure how efficiently management manages its company and also estimates future profitability based on sales forecasting made by its management. Hypotheses 3 , profitability has positive effect to the tax avoidance. By comparing net income with total sales, investors can see what percentage of income is used to pay for operational costs and non-operating costs and what percentage is left over which can pay dividends to shareholders or invest back into the company. The more profit generated, the greater the tax that must be paid. This result was same with prior result like although we used net profit margin as difference measurement for profitability (2),(13),(6). As a result shows that the net profit margin has positive and significant effect on tax avoidance. The greater the value of the net profit margin, the better the financial condition of the company. Firms have an ability to pay taxes well. But unconditionally, if the companies have small profit, then the company will act to make tax savings as much as possible.

\subsection{Relationship between size, leverage and total asset turn over to tax avoidance}

As the result, size, leverage and total asset turn over are control variables to tax avoidance. Size and total asset turn over have positive effect but not significant. Size has positive effect but not significant. In this research, It means that if total asset increase, tax obligation of firm will be increase too. But, size of company does not important factor effect to manager to save tax cost. Total asset turn overs have positive effect but not significant. It means that company use their sales for raise asset increase will effects to tax avoidance. More asset that company have, it will be more tax obligation that company should be comply. But in this case, this ratio is not important factor that manager will save the tax. Another difference with leverage, the result showed that leverage has negative effect and significant. When leverage increase, it will decrease tax avoidance.

\section{Conclusion}

Executive characteristics effect on how to manager make decision about tax avoidance, in this case. Executive characteristics has not significante effect to tax avoidance. . As per result above, we khow conclude that executive characteristic have not effect to tax avoidance, it is mean that whatever the character of executive is not impact to decision of tax avoidance, they assume that paying tax is mandatory for company. Independent commissioners are person who do over seeing and control the management decision. The number of independent commissioners has negative effect to tax avoidance. The net profit margin has positive and significant effect on tax avoidance.

\section{Limitation and Future Research}


This paper still have limitation, such as: the variables independent which were use only complementary about $46,1 \%$ to dependent variable. This research was only using manufacturing company as the sample. For future research, we suggest to measure executive characteristics using primer data, like questioner with psychology approach with hope that the characteristics executive can be measure about behaviour of manager.

\section{References}

1. Syed Haider Ali Zaidi, Xin-Yu Wang, Sardar Ahmad \& T-XP. Panama Papers and the dilemma of global financial transparency. International Journal of Modern Research in Management IJMRM International Journal of Modern Research in Management, 1(2). 2018; Available from: www.ijournalmrm.com

2. Desai, M. A., \& Dharmapala D. Corporate tax avoidance and firm value. Review of Economics and Statistics, 91(3), 537-546. 2009; Available from: doi.org/10.1162/rest.91.3.537

3. Direktorat, S., \& Pajak J. Surat Edaran Hal : Penetapan Rasio Total Benchmarking Tahap III Direktur Jenderal Pajak, Menindaklanjuti ketentuan angka 7 ( tujuh ) Surat Edaran Direktur Jenderal Pajak nomor SE- 96 / PJ / 2009 tanggal 5 Oktober 2009 tentang Rasio Total Benchmarking Dan. 2010;

4. Bradbury B, Discussion S, No P. TAX THEORY AND TARGETING A SURVEY by Bruce Bradbury. SPRC Discuss Pap No 100. 1999;(100).

5. Carolina V, Natalia M, Debbianita. Karakteristik Eksekutif Terhadap Tax Avoidance Dengan Leverage Sebagai Variabel Intervening. J Keuang dan Perbank [Internet]. 2014;18(3):409-19. Available from: http://jurkubank.wordpress.com

6. Shambara, Y. K. Shambara, Y., Kompyurini, N., Kecenderungan, M., Melakukan, P., Pajak, P., Sambharakreshna, Y., ... Trunojoyo, U. (2016). Yudhanta Shambara K., Nurul Kompyurini, 12(2), 1-6. 2016;

7. Saputra MF, Rifa D, Rahmawati N. Pengaruh corporate governance, profitabilitas dan karakter eksekutif terhadap tax avoidance pada perusahaan yang terdaftar di BEI. J Akunt Audit Indones [Internet]. 2015;19(1):1-12. Available from: doi.org/10.20885/jaai.vol19.iss1.art1

8. Maharani I, Suardana K. Pengaruh Corporate Governance, Profitabilitas, Dan Karakteristik Eksekutif Pada Tax Avoidance Perusahaan Manufaktur. E-Jurnal Akunt [Internet]. 2014;9(2):525-39. Available from: doi.org/10.20885/jaai.vol19.iss2.art1

9. Kartana IW, Wulandari NGA. Pengaruh Karakter Eksekutif , Karakteristik Perusahaan dan Corporate Governance pada Tax Avoidance. J KRISNAKumpulan Ris Akunt [Internet]. 2018;10(1):1-13. Available from: http://dx.doi.org/10.22225/kr.10.1.708.1-13

10. Dyreng SD, Hanlon M, Maydew EL, Thornock JR. Changes in corporate effective tax rates. 2014;

11. Mappadang. The Effect of Corporate Governance Mechanism on Tax Avoidance: Evidence from Manufacturing Industries Listed in the Indonesian Stock Exchange. The International Journal of Social Sciences and Humanities Invention, 5(10), 5003-5007. 2018; Available from: doi.org/10.18535/ijsshi/v5i10.02

12. Fadhila NS, Pratomo D, Yudowati SP. Pengaruh Kepemilikan Manajerial, Komisaris Independen dan Komite Audit Terhadap Tax Avoidance. E-Jurnal Akunt Univ Udayana. 2017; Vol. 21.3(Desember):1803-20.

13. Hidayat WW. Pengaruh Profitabilitas, Leverage Dan Pertumbuhan Penjualan Terhadap Penghindaran Pajak. J Ris Manaj dan Bisnis Fak Ekon UNIAT. 2018;3(1):19-26.

14. Jensen MC, Meckling WH. Theory of The Firm: Managerial Behavior, Agency Costs and Ownership Structure. J financ econ [Internet]. 1976 [cited 2019 Jun 26];3:305-60. Available from: http://117.211.153.211:8001/jspui/bitstream/123456789/335/1/1-s2.00304405X7690026X-main.pdf

15. Waluyo W. the Effect of Good Corporate Governance on Tax Avoidance: Empirical Study of the Indonesian Banking Company. Account J Binaniaga [Internet]. 2019;2(02):1-10. Available 
from: doi.org/10.33062/ajb.v2i02.92

16. Kawasan DI, Bagi P, Menengah M. Sjdi hukum pusat hukum dan humas. 2007;

17. Akuntansi J, Padang PN, Akuntansi D, Indonesia U. Pengaruh pemegang saham pengendali, komite audit, komisaris independen terhadap penghindaran pajak. 2016;(2011):15-6.

18. Afni Z, Hermawan AA. Pengaruh pemegang saham pengendali, komite audit, komisaris independen terhadap penghindaran pajak. Natl Conf Appl Sci Eng Bus Inf Technol. 2016;(2011):15-6. 